\title{
Iran Defensive Attitudes Towards United States' Offensive Politics: Analysis of Iran's Nuclear Development Programs
}

\author{
Ahmad Zainal Mustofa \\ Postgraduate of UIN Sunan Kalijaga Yogyakarta \\ Email:m.ahmadzainal@gmail.com
}

\begin{abstract}
Abstrak
Artikel ini menjelaskan tentang sikap yang ditunjukkan Iran terhadap serangan, tekanan, maupun kecaman Amerika Serikat khususnya dalam program perkembangan nuklir mereka. Melalui teori ofensif-defensif dari Stephen van Evera, artikel ini menjelaskan empat determinan yang menjadikan Iran akhirnya menerapkan sikap defensif terhadap sikap ofensif dari Amerika Serikat. Empat determinan tersebut meliputi perkembangan teknologi militer, kondisi geografis, konstelasi sosial politik, dan tatanan diplomasi. Selanjutnya artikel ini memaparkan empat determinan tersebut dan mengaitkannya dengan program pengembangan nuklir Iran dan juga respon dari Amerika Serikat. Dengan demikian, terlihat bahwa Iran menunjukkan sikap defensif terhadap sikap ofensif Amerika Serikat.
\end{abstract}

Kata kunci: Ofensif, Defensif, Pengembangan nuklir Iran, Amerika Serikat, Sosial politik.

\begin{abstract}
:
This article explains the attitude that Iran shows towards the attacks, pressures, and condemnation of the United States, especially in its nuclear development program. Through Stephen van Evera's offensive-defensive theory, this article explains four determinants that led Iran to finally adopt a defensive attitude towards all offensive from the United States. the four determinants include the development of military technology, geographical conditions, socio-political constellation, and the order of diplomacy. Furthermore, this article describes the four determinants and relates them to Iran's nuclear development program
\end{abstract}


and the response of the United States. Thus, it appears that Iran is showing a defensive towards the United States offensive.

Keywords: Offensive, Defensive, Iran's nuclear development, United States, Social politics.

\section{INTRODUCTION}

Iran's nuclear program is currently a hot issue discussed internationally. the development of this technology is reaping the problems of the United States and other Western countries, which incidentally already has thousands of nuclear weapons. According to data obtained from the Stockholm International Peace Research Institute (SIPRI), there are at least eight countries that have around 4,400 operational nuclear weapons. These countries are the United States, Russia, Britain, France, China, India, Pakistan, and Israel (Herianto, 2013, p. 168).

Iran's efforts in developing nuclear weapons technology have not been in vain. They get a lot of support from non-aligned countries. Iran is indeed active in building relations by doing diplomatic missions and is also intensely approaching its nonaligned countries on an ongoing basis. Fortunately, Iran's efforts get a quick response from these countries, marked when representatives of non-aligned countries announced support for Iran over the development of the nuclear program at a meeting of members of the International Atomic Energy Agency (IAEA) (Gogary, 2013, p. 143).

However, not all countries, especially Western countries, welcome the development of Iran's nuclear technology. the United States is the most violent country in opposing Iran's nuclear program. Most recently, when Iran conducted missile weapons testing for national defense, the US accused it as a program violating UN resolution (Kompas, 2018).

The United States always tries to stop Iran's domination in the Middle East region, because they are doing propaganda to prevent other developing countries from maintaining its existence as a Super Power country. in early 2002, US then-President George Herbert Walker Bush said in a congress the «axis of evil,» which included North 
Korea, Iran, and Iraq (Brinkley, 2004, p. 945). Although Bush's speech was devoted to Iraq under Saddam Hussein's leadership, the US still regarded Iran as a to-watchout-for enemy.

Furthermore, the author focuses on the attitude shown by Iran through its nuclear program developed towards American pressure and attacks from various angles and sides, since various efforts have also been made by the United States to prevent Iran from developing its weapons further. the author tries to untangle the tension between the United States and Iran in its nuclear development program using offensive-defensive theory.

\section{RESEARCH METHOD}

The research method used is a descriptive-analytical method, which is a method of collecting data by gathering relevant data to the discussion first, then analyzing them. the data collection technique used in this study was the documentation technique. Documentation technique is a technique of collecting data sourced from documents, such as books, journals, newspapers, magazines, and research reports as research data (Moehnilabib, 1997, p. 89). the author will describe Iran's defensive attitude actualized in concrete steps, especially regarding Iran's nuclear program to deal with pressure from the United States. the author filtered all sources to produce accurate data accommodating forms of tension that occurred substantially and permanently.

The theory used was Stephen Van Evera's offensive-defensive theory. This theory adopts the concept of a security dilemma owned by Robert Jervis. the security dilemma itself can be a form of action and reaction that occurs in countries. Actions taken by one country in increasing its security will have an impact on the protection of another country as an effort to weaken the safety of these countries (Alghifari \& Letticia, 2016 , p. 20). the basic pattern of offensive-defensive theory balance is that when offense dominates, what happens is an increase in the security dilemma, then followed by arms competition. Eventually, war will likely occur. However, people can avoid it through defense more dominant than offense (Glaser \& Kauffman, 1998, p. 45).

Based on this explanation, the author will describe Iran's behavior based on four determinants contained in the offensive-defensive theory in which Iran's position is as 
a defender, as follows (Evera, 1998, p. 16-22):

a) Military Technology and Doctrine

For the aggressor country or the defender country, military technology can undoubtedly benefit them. the change accompanied by an increase in military capability will be from data on Iranian spending and spending. the author will, of course, see the difference in the perception of the United States government as a factor that makes Iran strengthen its military.

b) Geography

Geographically, Iran is adjacent to the Persian Gulf, the Gulf of Oman, and the Caspian Gulf. Being in a strategic position for trade routes certainly makes America want to control the region to secure its national interests. Besides, Iran's geographical location holds substantial resources. These resources come from oil and gas reserves, whose production costs are lower than other oilproducing countries (Printina, 2019, p. 50).

c) Political and Social Order The 1979 Iranian Revolution was the momentum of Ayatollah Khomeini to use his influence in changing foreign policy, especially with the US. Khomeini has laid Iran's political foundation that is not in line with the US, then followed by his successors. It is the starting point for the emergence of attacks and unrelenting pressure from the US.

d) Diplomatic Arrangement

Iran conducts diplomacy with US non-affiliated alliance countries as back-ups in strengthening the country's resilience, also supported by the strengthening of Iranian military forces as an essential element to face national threats that could occur at any time.

\section{DISCUSSION}

\section{Technology and Military Development}

In 1960, Iran, then led by president Shah Reza Pahlavi, developed its nuclear power. At that time, Iran received a lot of help from Western countries such as America, Germany, and France. Iran's nuclear installation was initially only for research purposes with 5 megawatts of power, which 
then began operating in 1967 , then added cooperation between Iran and France and Germany for the construction of power plants. However, on its way, when the end of Reza Pahlavi's rule, Iran's cooperation with these Western countries ended. Iran continues its nuclear development program after the revolution without the will of the West. This issue is what triggers Iran in the Western view as a power that can endanger them, no longer as partners (Sahide, 2017, p. 154).

In 1979, Iran underwent a revolution, and relations between the two countries became broken. Muslim politics also became very influential towards the end of the 20th century, both on the perception of Islam and Muslim and Western relations. This issue continues to haunt the US causing distrust and shock due to the fall of the Pahlavi's regime. the White House worries about the emergence of radical Islamic fundamentalism or Khomeinism, which will spread to other countries after this revolution (Esposito, 2010, p. 99). Ayatollah Khomeini, as the leader of the Iranian revolution, even gave the nickname to America as the Great Satan. It is what makes America always blame Iran as a country that causes conditions in the Middle East to deteriorate, especially in the Gulf region. Unfortunately, relations between Iran and America also reheated when Mahmoud Ahmadinejad was elected president of Iran. America began to shake Ahmadinejad with various issues, including nuclear issues. the controversy over Iran's nuclear program by the US becomes a revisionist force in the Middle East regional system. It is this factor that makes America see Iran as a serious threat to US interests in the Middle East. According to America, Iran is slowly but surely becoming the leading country in the Middle East region Sahide, 2013, p. 100-102).

The government, the Iranian military, and also its population widely support Iran's nuclear program. At the same time, obtaining nuclear weapons capability is rarely explicitly supported by Iranian officials or others. Nuclear weapons are regularly as counterproductive and anti-Islamic. All of Iran's nuclear infrastructure - underground enrichment facilities in Natanz, uranium conversion plants in Esfahan, Bushehr nuclear power plant, heavy water plutonium production plant in Arak, and enrichment facilities in Qom, located inside a mountain base operated by Revolutionary Guards 
- shows the Iranian leadership. It is pursuing nuclear capabilities that can lead to the production of operational nuclear weapons.

After the end of the Iran-Iraq War, the nuclear program had a revitalization. There was significant progress during the presidency of Khatami (1997-2005), which in turn was a relatively moderate and pragmatism period in Iran's foreign policy. Khatami sought a policy of engagement with the IAEA and the European Union (EU) to reach a compromise on the nuclear program. Iran even suspended uranium enrichment in 2003 as a sign of commitment. Khatami's policy does not lead to a complete halt to the nuclear program, but it did open up opportunities for Iran and the international community to resolve the nuclear standoff. It also facilitated Khatami's efforts to reduce Iran's isolation and improve relations with critical regional countries, such as Saudi Arabia, and with European powers, such as France and Germany. As a result, Iran was able to attract more significant foreign trade and investment (Davis et al., 2011).

\section{Nuclear Program Agreement}

Today, the development of science and technology is progressing so rapidly, not least in terms of the use of nuclear power. the development of nuclear technology is indeed inseparable from the conditions and political situation during the world war. It causes developed nuclear technology to make weapons for war in the form of nuclear bombs. From this fact, the term nuclear is often associated with weapons (Akhadi, 1997, p. 10). Nuclear weapons are the primary concern of countries in the international community, both for the owner and non-possessor of nuclear weapons. Nuclear tests conducted by countries outside $\mathrm{P} 5$ pose a threat not only to P5 countries themselves but to the international community in general. Nuclear is a problem that disrupts global security and causes the future of world peace on the verge of collapse (Yustiningrum, 2016, p. 24). the figure of Nuclear Ownership Countries, 2018 


\section{Nuclear weapons by country, 2018}

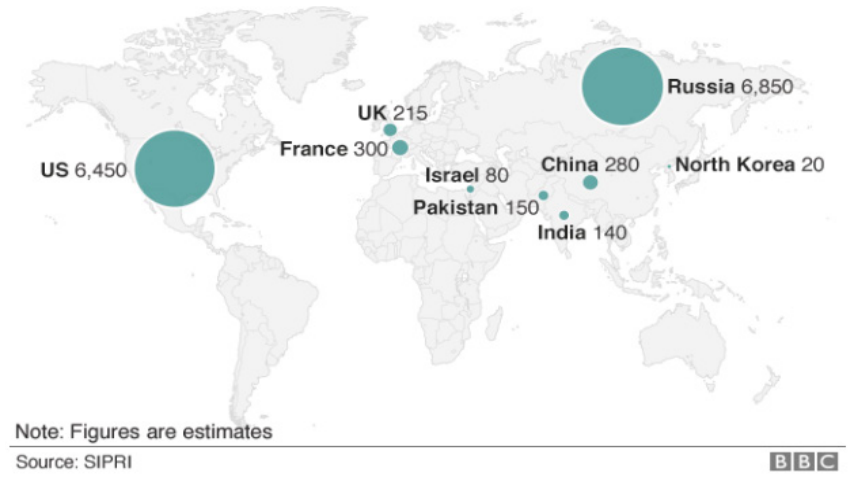

In 2015 , there was a world nuclear agreement that was mutually agreed upon by Britain, France, Germany, China, Russia, and the US. the critical parameter of the Joint Comprehensive Plan of Act (JCPOA) is a discussion of the Islamic Republic of Iran. the nuclear program agreement took place in Lausanne, Switzerland. the main points of the debate on the deal, are (jps.ucpress.edu, 2015):

1. Iran has agreed to reduce about two-thirds of the installed centrifuges. Iran will change from having around 19,000 installed today to 6,104 installed according to the agreement, with only 5,060 uranium looking rich for ten years. All6, 104 centrifuges are IR-1, Iran's first-generation centrifuges. Iran has agreed not to enrich uranium by more than 3.67 percent for at least 15 years.
2. Iran has decided to reduce its current stockpile of around $10,000 \mathrm{~kg}$ of lowenriched uranium (LEU) to 300 kilograms from 3.67 percent LEU for 15 years. All centrifugal infrastructure and over-enrichment will be placed in IAEA-monitored storage and will only be used as a replacement for outward operations and equipment.

3. Iran has agreed not to build new facilities to enrich uranium for 15 years.

4. Iran's flight timeline - the time needed for Iran to get enough fissile material for one weapon - is currently valued at 2 to 3 months. That time frame will be extended at least one year, for at least ten years, under this framework.

After reaching an agreement from the negotiations, on July 
14, 2015, US President Barack Obama held a press conference at the White House. He explained that the negotiations aimed to spread the distribution of nuclear weapons in the Middle East so that the international community could ensure that Iran would obey and respect this agreement by not developing nuclear weapons. the argument presented by Obama regarding the nuclear deal with Iran is that America is free from potential direct threats to the national security of its country, which can come from countries that possess nuclear weapons. Iran is one of the states noted by America, especially in Bush's era as a country to watch out for and anticipate (Rofii, 2015, p. 32).

With Iran's oil production reaching 2 million barrels per day, the US hopes to partner with them again to meet the needs of large-scale energy supply. This step will benefit the US so that it can compensate for Russia, which dominates Iran. Besides, Western countries' embargoes have narrowed Iran's market reach in the past decade. the US and the UK are the countries that will benefit from the situation. the two countries that have economic motives will use the oil sector, such as Shell, Chevron, and British
Petroleum, to get involved in Iran's oil and gas exploration projects. the latest technology owned by the West can produce Iranian oil by 3.3 million barrels per day. US and European entrepreneurs choose a realistic strategy from this causality. They will get oil and gas resources, while Iran will be able to expand its market reach to an international level (Rofii, 2015, p. 33).

\section{Doctrine and Geographic Conditions}

Iran has the doctrine of military defense as the world countries in general. Nevertheless, Iran is unique in the aspect of military security. the uniqueness lies in Iran's defense strategy that relies on strengthening to defend from enemy attacks. It is the main philosophy and doctrine of Iran's military defense system. the doctrine of this defensive teaching comes from the teachings of Islam, in which the history of Islam itself shows how the Prophet Muhammad never started a war.

All types of warfare carried out by the Prophet Muhammad are in the context of resistance and selfdefense against enemies who attack and want to wipe out Muslims along with Islam. Islam does not allow its people to be aggressive, but Muslims must be firm, and always ready to 
face all possible invasions from outside. This formidable defense will, in turn, avoid or reduce the enemy's bad intentions to attack. the phrase that had been conveyed by Ayatullah Khomeini to the Iranian military commanders made the nationalism spirit of the combat troops burn. They are to maintain the defense and security of the country from various enemy threats. However, they also will not be rash and without calculation in deciding something. They believe that a defensive strategy is the best way to make enemies think twice if they want to attack them.

Before the Iranian Revolution, the US considered Iran as an essential economic partner by looking at the results of its location and geographical conditions. Iran, as a 'silk route' and an abundant producer of gas and petroleum, makes the US not miss the opportunity to establish cooperation. Both of them established trade relations in the military and petroleum fields. the US is a significant supplier of weapons to Iran to meet the needs of combat weapons. Also, about $20 \%$ of all oil obtained by the US comes from the Middle East plains. But behind it all, there is a secret mission brought by the US and one of its interests behind cooperation with Middle Eastern countries. the purpose is to remove the influence of the Soviet Union from the Arab world. the US wants to invest three things to strengthen its impact, namely: First, exploiting natural resources to gain as much wealth as possible. Second, the US wants to change the ideology in the Middle East that is synonymous with using the Islamic system by turning it into an ideology of liberal democracy. Third, the US's desire to dominate the power in the Middle East to achieve glory (Sahide, 2019, p. 154).

The Iranian Revolution has changed the political constellation and US national interests in the Middle East. the US and Israel are the countries affected by the revolution and have suffered many losses. the US has lost its guaranteed security of the oil routes they desperately need, while losing partners to its modern weapons industry (Sahide, 2013, p. 94). Ayatollah Khomeini created an ideological idea in which Islam was by combining Iranian nationalism, which originated in religion and belief in the transnational character and the global mission of Muslims through propaganda, role models, and weapons revolutions to spread Islam. This idea is exporting Islam Revolutionary (Esposito, 1996, p. 127). the influence of Iran's 
dependence on the US is slowly disappearing. Iran can stand without US assistance. in addition to voicing as an anti-imperialist state, Iran is also very concerned about its defense and security aspects, which are essential aspects of defending the country.

\section{Social and Political Constellations}

Iran is a country with a systematic strategy in determining policy so that Iran is not afraid of US criticism. Even the US efforts to immerse Iran so far have not produced maximum results yet. the US worries if Iran will dominate the Middle East region because this will make the US lose its influence in the area. There are at least seven reasons why America did not attack Iran, namely (dunia.tempo.co, 2019):

1. Iran has qualified military skills to deal with the United States in recent decades. Iran also has experience in learning US tactics and strategy through observation during the decade of the Iraq war.

2. The Iranian Army and the Iranian Revolutionary Guard Corps will not put their weapons on the initial attack. Iran will not just give up on the initial US attack.

3. Iran's Intelligence Ministry is one of the best in the world.

4. The Hezbollah Resistance Movement is likely to assist Iran's resistance to the US.

5. Iran has impressive capabilities in the development of cyberspace.

6. The US military deserves a rest after nearly a decade of the continuing war.

7. The US attack on Iran will bring the United States into a bigger war.

The seven reasons reinforce that the United States cannot attack Iran directly. Hence, the US uses the nuclear issue and, even more recently, is an Iranian missile test as a propaganda tool to undermine Iran's image in the international world. the United States is well aware that if it conducts a direct attack on Iran, then the US will get a lot of damage.

During this time, Western countries have turned a blind eye to Israeli nuclear bombs that threaten security and peace in the Middle East. But on the contrary, they always suppress and prevent Iran from possessing nuclear and nuclear technology, even though it is one of the most simple and legal rights of the Iranian people. Iran's closeness to Venezuela, Cuba, North Korea, 
China, and Russia has raised fears for America. They worry that the international front against American imperialism and hegemony will form after the ineffectiveness of the non-aligned movement. the fear of the United States is increasing, especially with the increasing relations and cooperation between Iran-China-Venezuela, especially in the oil sector (Gogary, 2013, p. 143144).

Western countries only focus on finding loopholes to weaken Iran in terms of military power and weapons. Iran must accept criticism after condemnation carried out by America and its allies. But Iran proves that they are a country that is not weak and timid. Iran remains unmoved by US efforts to stop its existence in developing weapons.

Implicitly, Khomeini's statement encouraging the military to strengthen weapons was an effort to prevent war. If Iran had a weak military defense, it might have long been Israel alone or with America attacking Iran. However, because Iran's air and sea defenses are substantial, including successfully dropping a US spy plane, the RQ170 Sentinel at the end of 2011, the facts made Israel think long before attacking Iran. Thus, Iran's military defensive doctrine is essentially deterrence or deterrence (Gogary, 2013, p. 178).

Iran's military budget statistics provide an accurate picture of the adoption of its defensive doctrine, even though the Iranian economy is ranked 17th largest in the world and facing threats of attack from the US. Psychologically, the shadow of the US threat could disrupt Iran's calm due to the psywar. However, Iran still has the confidence to uphold the principle of defensive defense. Even though Iran currently has a low budget, the region highly respects the Iranian military. the following is a list of Military Expenditures from the top 5 countries (Herianto, 2013, p. 179):

\begin{tabular}{|l|c|c|}
\hline \multicolumn{1}{|c|}{ Countries } & Military Expenditures Budget 2010 (\$) & \% in 2009 \\
\hline 1. USA & $\$ 698,105,000,000$ & $4,7 \%$ \\
2. China & $\$ 114,000,000,000$ & $2,2 \%$ \\
3. France & $\$ 61,285,000,000$ & $2,5 \%$ \\
4. UK & $\$ 57,424,000,000$ & $2,7 \%$ \\
5. Russia & $\$ 52,586,000,000$ & $4,3 \%$ \\
6. Iran (number 25) & $\$ 9,174,000,000$ & $1,8 \%$ \\
\hline
\end{tabular}


Iran is a budget-saving country for military spending, proved by Iran's success by ranking 25th in the world, even in the 6th largest in the Middle East. Still, Iran is an independent country. They use domestic scientists and engineers to produce weapons tailored to their defensive needs. This Iranian effort can save high costs. Iran prefers soft power in strengthening its country, namely culture, science and technology, and foreign policy (Herianto, 2013, p. 179-181).

In contrast to Iran, the US allocates more funds for defense. With the number of defense equipment of the two countries today, the United States military strength is far more reliable than Iran. the following are data on the military power of the United States and Iran in 2019 (globalfirepower. com, 2019):

\begin{tabular}{|l|c|c|}
\hline \multicolumn{1}{|c|}{ Military Forces } & USA & Iran \\
\hline 1. Budget & $\$ 716,000,000,000$ & $\$ 6.300 .000 .000$ \\
2. Active Personnel & $1,281,900$ people & 532,000 people \\
3. Land Defense & 6,287 weapons & 1,634 weapons \\
4. Marine Defense & 415 weapons & 398 weapons \\
5. Air Defense & 13,398 weapons & 509 weapons \\
\hline
\end{tabular}

The two tables above prove that, even though Iran has a minimal military budget and less military power compared to the United States, it has other ways to manage both, starting from a defensive strategy, using scientists and engineers to prioritize soft power. It is what the United States scares from Iran.

In May 2018, US President Donald Trump withdrew from the international nuclear agreement and reinstated sanctions on Iran.
Trump criticized the deal because there were no points of restriction on the development of Iranian defense equipment, according to him. Trump said that he would not let Iran continue to develop nuclear because it could threaten US national defense. Nuclear agreement that is valid until 2030 is to make Iran free to continue its nuclear development program, so that it will create a contestation of nuclear weapons ownership in the 
Middle East (international.kompas. com, 2019).

Furthermore, the US officially left the Iranian nuclear agreement on May 8, 2018, and again imposed economic sanctions on him. the United States has still harassed Iran by entering a new phase. the US is very objected to the ballistic missile test activities carried out by Iran. However, Iran reiterated that its missile program was only for defense testing. Not only that, but the US also tried to influence other countries to simultaneously criticize Iran, seen by the US's insistence on the United Nations Security Council (UNSC) to denounce Iran. on the other hand, the US also does not hesitate to impose sanctions on Iran, even for the most stringent ones.

\section{Iran Diplomatic and United States Pressure}

US concern about Iran is a situation that can undoubtedly disturb the sound sleep of the White House. Ahmadinejad's strict statement that Iran will remain consistent with the principles of the 1979 Islamic Revolution further aggravated the condition. Also not spared, Iran responds to all forms of political maneuvering carried out by Western countries. So far, Iran has also been active in establishing diplomatic relations with outside countries such as Russia and North Korea providing an injection of strength both morally and materially so that Iran can stand firm under US pressure. of course, the countries that Iran embraced to form diplomacy are US non-affiliated countries. This strategy also makes the US pressure the intensity against Iran.

In the Obama era, the US conducted foreign policy towards Iran by imposing economic sanctions and damaging the stability of the Iranian economy by reducing imports of oil and its petroleum products. the action aimed to isolate vital objects such as the Central Bank of Iran, which has an essential role in regulating Iran's trade flows. Obama also wanted Tehran to stop nuclear development activities. Even Obama directly threatened foreign investors who were still in the oil business with Iran. the threat was in the form of decisive action against financial institutions in their countries (dw.com, 2012).

The pressure on Iran does not end there. Efforts to intervene in Iran in the Trump era are much stricter. Trump gave a warning to any countries cooperating with Iran. They will not be allowed to establish cooperation with the US. Trump 
issued this statement after the US left the Iranian nuclear agreement and re-imposed sanctions on Iran (bbc.com, 2018). the US's strong stance by imposing full sanctions on Iran aimed to make them feel pressured that they wanted to reopen negotiations with the US regarding its nuclear program. the US also hoped that the countries involved in the signing of the JCPOA could follow in his footsteps so that Iran would be in a challenging and increasingly pressured condition (Rahim, 2019, p. 31).

US foreign policy towards Iran during Obama and Trump are relatively similar. the two US leaders imposed severe sanctions to pressure the government in Tehran. Even Trump continues to exert pressure by conducting a psywar against Iran, especially after the US officially left the Iranian Nuclear Treaty and maintains a new round of implementing sanctions for Iran. the US is pressing Iran from various sides, such as bilateral and multilateral policies. With the repressive attitude shown, the US hopes that its systems can provide turbulence for Iran's foreign policy, especially in the economic and trade fields. This condition is essential. If the economy and business are thriving, then what happens is domestic instability that can lead to conflict and division. This kind of situation is what the US wants to maintain dominance in the Middle East region without interference from Iran.

\section{CONCLUSION}

Based on the above discussion, Iran uses a defensive stance in the face of pressure and attacks from the United States. Four determinants describe Iran as a defender. the first is technological and military developments embodied in the nuclear development program, and the second is Iran's geographical condition as a 'silk route' and abundant oil and gas producers. Third, the social and political constellation of Iran is so systematic in determining policy, in which Iran in producing weapons is more utilizing the engineers and scientists they have. Fourth is Iran's diplomatic order by embracing non-affiliated US countries. Iran's defensive attitude is to offset the offensive manner carried out by the United States. Although it does not attack America directly, Iran is always alert and ready at any time if America wants a war. Until now, America does not have enough courage to fight and attack Iran directly. Instead, they only 
denounce it with a variety of things, accusations, and reasons, especially regarding nuclear. It launches these criticisms with the hope that Iran could not move anymore and do anything to develop its weapons.

\section{REFERENCES}

(2015). the Iran Nuclear Negotiations: Israel and the U.S. Congress. Journal of Palestine Studies, 44, 4, 68-92. https://doi. org/10.1525/jps.2015.44.4.68

Alghifari, Fadhil \& Raja Nathania Olga Letticia. (2016). Analisis Teori Offense-Defense terhadap Reformasi Kebijakan Pertahanan Jepang dalam Dinamika Keamanan di Asia Timur. Global: Jurnal Politik Internasional, 18,1, 18-33.

Bakhash, Shaul. (2009). from https:// www.fpri.org/article/2009/09/ the-u-s-and-iran-in-historicalperspective/

Brinkley, Alan. (2004). the Unfinished Nation: A Concise History of the American People Volume II: From 1865. New York: Lyn Ubl.

Davis, Lynn E., etc. (2011). Iran's Nuclear Future: Critical U.S. Policy Choice. United States: RAND Corporation.
Esposito, Jhon L. (2010). Masa Depan Islam: Antara Tantangan Kemajemukan dan Benturan dengan Barat. (Terj. Eva Y. Nukman dan Edi Wahyu SM.). Bandung: Mizan Pustaka. (1996). Ancaman

Islam: Mitos atau Realitas? (Terj. Alwiyah Abdurrahman dan MISSI). Bandung: Mizan.

El-Gogary, Adel. (2013). the Nuclear Savior of Tehran: Sang Nuklir Membidas Hegemoni AS dan Zionis. Depok: Pustaka Iman.

Evera, Stephen van. (1998). Offense, Defense, and the Causes of War. International Security, 22, 4, 5-43.

Glaser, Charles L. \& Chaim Kaufmann. (1998). What is the Offense-Defense Balance, and Can We Measure It? International Security, 22, 4, 44-82.

Herianto, Husain. (2013). Revolusi Saintific Iran. Jakarta: UI Press. Moehnilabib, dkk. (1997). Dasardasar Metodologi Penelitian. Malang: Lembaga Penelitian IKIP Malang.

Printina, Brigida Intan. (2019). Analisa Potensi Geografis Timur Tengah Menjadi Kekuatan Teritori Melalui Komik Digital Berlandaskan 
Paradigma Pedagogi Reflektif. Jurnal Agastya, 9, 1, 44-55.

Rahim, Muhammad Halil. (2019). Post-JCPOA: Diplomasi Koersif Amerika Serikat VisÀ-Vis Iran. Jurnal ICMES, 3, 1, Juni, 27-52.

Riedel, Bruce. (2008). America and Iran: Flawed Analysis, Missed Opportunities, and Looming Dangers. the Brown Journal of World Affairs, 15, 1, 101-111.

Rofii, M. Sya'roni. (2015). Babak Baru Nuklir Iran: Memahami Manuver Iran dan Dinamika Politik Kawasan Timur Tengah. 1, 1, 27-39, from https://www.researchgate. net/publication/318774708_ Babak_Baru_Nuklir_Iran_ Memahami_Manuver_Iran_ dan_Dinamika_Politik_ Kawasan_Timur_Tengah
Sahide, Ahmad. (2019). the Arab Spring: Tantangan dan Harapan Demokratisasi. Jakarta: Kompas. . (2017). Gejolak Politik Timur Tengah: Dinamika, Konflik dan Harapan. Yogyakarta: the Phinisi Press. . (2013). Ketegangan Politik Syiah-Sunni di Timur Tengah. Yogyakarta: the Phinisi Press.

Wise, Krysta. (2011). Islamic Revolution of 1979: the Downfall of American-Iranian Relations. Legacy, 11, 1-16.

Yustiningrum, RR. Emilia. (2016). Masalah Senjata Nuklir dan Masa Depan Perdamaian Dunia. Jurnal Politik LIPI, 1932. 